\title{
Environmental tobacco smoke exposure at home and smoking prevalence in the general Portuguese population-The INAsma study
}

\author{
A.M. Pereira ${ }^{a, b, c, *}$, M. Morais-Almeida ${ }^{b, d, e}, A$. Sá e Sousa ${ }^{b}$, T. Jacinto ${ }^{b, c, f}$, \\ L.F. Azevedo ${ }^{b, f}$, C. Robalo Cordeiro ${ }^{g, h}$, A. Bugalho de Almeida ${ }^{d, i, j}$, J.A. Fonseca ${ }^{a, b, c, f}$
}

a Serviço de Imunoalergologia, Centro Hospitalar São João, Porto, Portugal

b Centro de Investigação em Tecnologias e Sistemas de Informação em Saúde, Universidade do Porto, Porto, Portugal

c Centro de Imunoalergologia CUF (Porto), Porto, Portugal

d Centro de Imunoalergologia CUF (Lisboa), Lisboa, Portugal

e Sociedade Portuguesa de Alergologia e Imunologia Clínica, Lisboa, Portugal

${ }^{\mathrm{f}}$ Departamento de Ciências da Informação e da Decisão em Saúde, Faculdade de Medicina, Universidade do Porto, Porto, Portugal

g Sociedade Portuguesa de Pneumologia, Lisboa, Portugal

h Departamento de Pneumologia, Centro Hospitalar Universitário de Coimbra Coimbra, Coimbra, Portugal

' Clínica Universitária de Pneumologia, Faculdade de Medicina de Lisboa, Lisboa, Portugal

${ }^{j}$ Comissão de Acompanhamento do Programa Nacional de Controlo da Asma, Lisboa, Portugal

Received 17 January 2012; accepted 3 January 2013

\section{KEYWORDS}

Environmental tobacco smoke; Smoking;

Asthma;

Heart disease;

Health survey

\begin{abstract}
Background: We aimed to: (1) estimate the prevalence of exposure to environmental tobacco smoke (ETS) at home in the Portuguese population; (2) estimate tobacco smoking prevalence in Portugal; (3) identify social and personal characteristics associated with smoking or exposure to ETS.

Methods: Nationwide, cross-sectional, population-based telephone survey. Overall, 6003 individuals completed the interview. ETS exposure at home was defined as exposure to at least one current smoker at home. A smoker was defined as someone with 15 years or older, smoking at least 1 cigarette per day during a year; a current smoker (CS) smoked in the last month.

Results: Exposure to ETS at home was reported by $26.6 \%(95 \% \mathrm{CI} 25.5-27.7)$ of the participants. Living in households with $\geq 4$ persons $(\mathrm{OR}=2.31 ; 95 \% \mathrm{Cl}[1.81-2.96])$, being a current smoker $(\mathrm{OR}=7.29 ; 95 \% \mathrm{Cl}$ [5.74-9.26]) or having current asthma $(\mathrm{OR}=2.06 ; 95 \% \mathrm{Cl}$ [1.45-2.94]) were factors positively associated with ETS exposure. When analyzed by gender, the effect of current asthma was only relevant to females.
\end{abstract}

Abbreviations: BMI, Body mass index; CATI, computer assisted telephone interview; $\mathrm{Cl}$, confidence interval; CS, current smoking; ECOS, Em Casa Observamos Saúde; ETS, Environmental Tobacco Smoke; GA²LEN, Global Allergy and Asthma European Network; INAsma, Portuguese National Asthma Survey; NUTS, Nomenclature of Territorial Units for Statistics; OR, Odds Ratio; ROC, Receiver operating characteristic; SD, Standard Deviation; SES, SocioEconomic Status; WHO, World Health Organization.

Please cite this article as: Pereira, AM; Prevalência da exposição ao fumo ambiental do tabaco em casa e do tabagismo na população Portuguesa - o estudo INAsma. Rev Port Pneumol 2013. http://dx.doi.org/10.1016/j.rppneu.2013.01.002.

* Corresponding author.

E-mail address: ambrpereira@gmail.com (A.M. Pereira).

2173-5115/\$ - see front matter @ 2012 Sociedade Portuguesa de Pneumologia. Published by Elsevier España, S.L. All rights reserved. 
Currently $19.0 \%$ (95\% Cl $18.0-20.0)$ of the Portuguese population smokes tobacco and $17.2 \%$ $(95 \% \mathrm{Cl} 16.2-18.2)$ are ex-smokers. CS prevalence is higher in males than females $(26.5 \%$ vs. $12.2 \%, p<0.001)$. The odds of being a CS were higher for males, the more educated, and those exposed to ETS at home. When analyzed by gender, school education only affected females.

Conclusion: Exposure to ETS at home was higher than previously reported. Children/adolescents and asthma patients may have a higher risk of exposure. This report endorses a decreasing trend in the prevalence of tobacco smoking in Portuguese males, but a tendency to increase in females.

(C) 2012 Sociedade Portuguesa de Pneumologia. Published by Elsevier España, S.L. All rights reserved.

\section{PALAVRAS-CHAVE}

Fumo ambiental do

tabaco;

Tabagismo;

Asma;

Doença cardíaca;

Inquérito de saúde

\section{Background}

Smoking is a leading cause of preventable disease and early death. ${ }^{1,2}$ Its negative effect on the health of smokers ${ }^{3}$ and nonsmokers ${ }^{4}$ is well-known. Worldwide, it is estimated that around one third of the population aged 15 or over ${ }^{5}$ smokes and one third of adults and $40 \%$ of children ${ }^{6}$ are regularly exposed to secondhand tobacco smoke.

Comprehensive and evidence-based tobacco control programs can substantially reduce tobacco use. ${ }^{7}$ The increase in cigarette taxes and comprehensive clean air laws seem to be the cornerstone of these strategies: each has the potential to reduce smoking prevalence by $10 \%$ or more. ${ }^{8}$ In 2003, the World Health Organization (WHO) created a
Framework Convention on Tobacco Control intending to implement multiple measures to reduce tobacco use and exposure to tobacco smoke; 172 countries ratified the convention, including Portugal. ${ }^{9}$ On August 14th, 2007, the Portuguese Parliament passed the law applying a partial ban to tobacco use; it entered into effect on January 1st, 2008. ${ }^{10}$

In Portugal, the data is limited and discrepant on the prevalence of tobacco smoking, especially after the 2008 legislative bans. Two series provided data on smoking prevalence before the law: one from the National Health Surveys showing low and stable prevalence in the last decade ${ }^{11}$; another, from the European Comission Eurobarometer, presenting higher smoking prevalence, but with a decreasing 
tendency after 2002. ${ }^{12}$ In the National Health Surveys, when considering gender-specific smoking prevalence, a trend for increasing prevalence in female and for a gradual decrease in male was shown. ${ }^{13}$ Recent studies ${ }^{12,14,15}$ reported smoking prevalence after the 2008 law, but results differed more than $8 \%$ (from 16.4 to $25.5 \%$ ).

With the implementation of the new smoking bans in work and public places, there were concerns that smoking at home, and consequently exposure to environmental tobacco smoke (ETS) at home, could increase. ${ }^{14}$ In other countries, legislation restricting smoking resulted in a greater adoption of voluntary bans on smoking at home. ${ }^{16,17}$ In Portugal, there is little information available on the prevalence of exposure to ETS at home in the general population before or after the law. ${ }^{12,15,18,19}$

The aims of this study were, in the Portuguese population, (1) to estimate the prevalence of exposure to ETS at home, (2) to estimate the prevalence of tobacco smoking, and (3) to identify social and personal characteristics associated with smoking or being exposed to ETS at home.

\section{Methods}

\section{Study design}

The Portuguese National Asthma Survey (INAsma, Inquérito Nacional sobre Asma) was a nationwide, cross-sectional population-based telephone survey targeting people of all ages who were resident in Portugal and had a landline telephone at home. The study design has been described in detail elsewhere. ${ }^{20}$ Briefly, to obtain a representative sample of the general population a two-stage cluster and stratified sampling design was used, including two steps. First, we selected a simple random sample of households within each municipality (stratum) using a list of landline telephone numbers; overall, 24,412 telephone numbers were selected. Second, within each selected household, one eligible household resident was randomly selected and invited to participate in the study. We decided that the participant would be the last person celebrating his/her birthday; when the selected individual was younger than 15 years we interviewed the usual caregiver. Individuals unable to understand spoken Portuguese or with cognitive or physical conditions hampering the interview were excluded. Of the selected numbers, 17,698 were contacted and 11,695 excluded based on exclusion criteria $(n=1569)$, refusal to participate $(n=6028)$, no answer to the phone call $(n=3059)$ or wrong numbers $(n=1039)$.

The study was approved by the Ethics Committee of Centro Hospitalar São João.

All participants gave oral informed consent.

\section{Instruments and data collection}

The INAsma was primarily designed to estimate the prevalence of asthma in the Portuguese population and was mainly based on the GA ${ }^{2}$ LEN survey. ${ }^{21,22}$ It had 7 questions related to characterization of tobacco smoking, including tobacco use and cessation and ETS exposure. Questions were asked about current asthma symptoms and known diagnosis of asthma or heart disease.
Table 1 Definitions of the variables used in the analysis.

\begin{tabular}{|c|c|}
\hline Variable & Definition \\
\hline Smoker & $\begin{array}{l}\text { Participant with } \geq 15 \text { years that } \\
\text { smoked at least } 1 \text { cigarette per day } \\
\text { (or a cigar/week) during a year } 22\end{array}$ \\
\hline $\begin{array}{l}\text { Current smoker } \\
\text { (CS) }\end{array}$ & $\begin{array}{l}\text { Smoker that smoked in the last } \\
\text { month }^{22}\end{array}$ \\
\hline Ex-smoker & $\begin{array}{l}\text { Smoker that stopped smoking at least } \\
\text { a month before the interview }{ }^{22}\end{array}$ \\
\hline $\begin{array}{l}\text { Non- } \\
\text { smokers/never- } \\
\text { smokers }\end{array}$ & $\begin{array}{l}\text { Participant with } \geq 15 \text { years reporting } \\
\text { neither smoking nor ex-smoking }\end{array}$ \\
\hline $\begin{array}{l}\text { Environmental } \\
\text { tobacco } \\
\text { smoke (ETS) } \\
\text { exposure at } \\
\text { home }\end{array}$ & $\begin{array}{l}\text { Positive answer to the question } \\
\text { "Anyone in your household smoke } \\
\text { cigarettes/cigars?" }\end{array}$ \\
\hline Current asthma & $\begin{array}{l}\text { Positive answer to the question } \\
\text { "Have you ever had asthma?" and at } \\
\text { least one out of three asthma } \\
\text { symptoms in the last } 12 \text { months: } \\
\text { wheezing, night awakening with } \\
\text { dyspnea or having asthma attack }\end{array}$ \\
\hline $\begin{array}{l}\text { Self-reported } \\
\text { heart disease }\end{array}$ & $\begin{array}{l}\text { Positive answer to "Do you have you } \\
\text { a heart condition?" }\end{array}$ \\
\hline $\begin{array}{l}\text { Chronic } \\
\text { bronchitis }\end{array}$ & $\begin{array}{l}\text { Positive answer to "Did you have } \\
\text { phlegm when coughing for at least } \\
3 \text { months in the last year?" and } \\
\text { smoked }>10 \text { pack-years and have } \\
\geq 40 \text { years old }\end{array}$ \\
\hline
\end{tabular}

Interviews were conducted between March and May of 2010 using computer-assisted telephone interview (CATI).

The definitions of the variables (smoking and disease statuses) are described in Table 1.

\section{Statistical analysis}

\section{Weighting procedures}

A set of weighting procedures were implemented in order to correct for sample imbalances and partially adjust prevalence estimates for non-response and non-coverage bias. Two types of weights were used: (1) weights adapted to the sampling design (stratification and two stage cluster sampling), adjusting for different probabilities of selection among respondents and (2) post-stratification weights adjusting for imbalances between the sample and the 2001 Portuguese National Census, taking into account population distributions by geographical region of residence, sex and 5 years age categories.

\section{Variable categorization and analysis}

Municipalities were recoded into regions according to the Portuguese Nomenclature of Territorial Units for Statistics (NUTSII) distribution. Body mass index (BMI) was recoded according to the WHO classification. ${ }^{23}$ Socioeconomic status was classified according to the job and school education level of the household family member with the highest income (Tables S1 and S2). School education was recoded in 
three categories taking into account the Portuguese school system. School education and BMI analysis was restricted to individuals of 18 years or older.

Categorical variables were described using absolute frequencies, proportions and 95\% confidence intervals ([95\% $\mathrm{Cl}]$ ). Comparisons of proportions were tested with Pearson Chi-Square. Continuous variables were described using mean and standard deviation (SD); comparisons were tested with the independent samples $t$-test. A $p$-value of $<0.05$ was considered statistically significant.

\section{Logistic regression}

Univariate and multiple logistic regression models were developed using independent variables as risk factors for current smoking and exposure to ETS at home in adults (considering those living with at least one other person in the household); results were presented as odds ratios (OR) with $[95 \% \mathrm{Cl}]$. Variables used in both models included gender, region, socioeconomic status (SES), school education, body mass index (BMI), number of persons in the household and disease statuses (current asthma or heart disease); exposure to ETS at home was included in the model for smoking; smoking status (current smoker vs. never-smoker) was included in the model for exposure to ETS; chronic bronchitis could not be included. We also tested interactions between the variables ( 2 by 2 ) in both models; the interaction between gender and school education was found to be important and was included in the final model for both smoking and ETS exposure. Gender-stratified models are also presented. Models were progressively adjusted considering their goodness-of-fit (assessed by Hosmer-Lemeshow test) and predictive power (evaluated by ROC curve analysis).

Statistical analysis was performed using SPSS ${ }^{\circledR}$ Statistics version 19 (IBM, Chicago, Illinois, USA).

\section{Results}

The characteristics of the 6003 participants are summarized in Table 2.

\section{Exposure to environmental tobacco smoke at home}

Home ETS exposure was reported by $26.6 \%$ of the participants (Table 3 ). More than half $(53.2 \%)$ of the CS were exposed to ETS at home while only $14.1 \%$ of the ex-smokers and $23.2 \%$ of the non-smokers reported exposure $(p<0.001)$. Children and young adults ( $<25$ years old) were the most exposed $(39.0 \%$ vs. $21.1 \%$ in the older population, $p<0.001)$ (Figure S1).

The prevalence of exposure to ETS at home was highest in those with asthma $(33.8 \%$ vs. $26.6 \%$ in the general population vs. $16.0 \%$ in those with self-reported heart disease) (Table 3).

In the adjusted multiple logistic regression model for exposure to ETS at home, in adults (Table S3), having a higher number of persons in the household $(O R=1.58$ [1.22-2.04] for 3 persons in the household and $\mathrm{OR}=2.31$ [1.81-2.96] for $\geq 4$ persons), being a current smoker $(\mathrm{OR}=7.29$ [5.74-9.26]) or having current asthma $(O R=2.06[1.45-2.94])$ were factors positively associated
Table 2 Characteristics of the participants $(n=6003)$.

\begin{tabular}{|c|c|c|}
\hline & $N$ & Non-weighted \% \\
\hline \multicolumn{3}{|l|}{ Gender } \\
\hline Male & 2565 & 42.7 \\
\hline \multicolumn{3}{|l|}{ Age groups } \\
\hline$<18$ years old & 716 & 11.9 \\
\hline 18-65 years old & 3104 & 51.7 \\
\hline$\geq 65$ years old & 2178 & 36.3 \\
\hline \multicolumn{3}{|l|}{ Region } \\
\hline North & 1993 & 33.2 \\
\hline Center & 1391 & 23.2 \\
\hline Lisbon & 1651 & 27.5 \\
\hline Alentejo/Algarve & 729 & 12.1 \\
\hline Madeira and Azores islands & 239 & 4.0 \\
\hline \multicolumn{3}{|l|}{ Socioeconomic status } \\
\hline Low & 1280 & 21.3 \\
\hline Medium & 4137 & 68.9 \\
\hline High & 405 & 6.7 \\
\hline \multicolumn{3}{|c|}{ School education ( $\geq 18$ years old) } \\
\hline$<9$ years & 3437 & 57.3 \\
\hline $9-12$ years & 1082 & 18.0 \\
\hline$>12$ years & 729 & 12.1 \\
\hline \multicolumn{3}{|l|}{ BMI groups ( $\geq 18$ years old $)$} \\
\hline$<25 \mathrm{~kg} / \mathrm{m}^{2}$ & 1958 & 32.6 \\
\hline $25-29.99 \mathrm{~kg} / \mathrm{m}^{2}$ & 1806 & 30.1 \\
\hline$\geq 30 \mathrm{~kg} / \mathrm{m}^{2}$ & 694 & 11.6 \\
\hline \multicolumn{3}{|l|}{ Persons in the household } \\
\hline$\leq 2$ persons & 3313 & 55.2 \\
\hline 3 persons & 1169 & 19.5 \\
\hline$\geq 4$ persons & 1521 & 25.3 \\
\hline Current asthma & 450 & 7.5 \\
\hline Self-reported heart disease & 821 & 13.7 \\
\hline Chronic bronchitis & 210 & 3.5 \\
\hline
\end{tabular}

BMI: body mass index.

with ETS exposure. Being $\geq 65$ years (vs. 18-64 years; $\mathrm{OR}=0.65$ [0.49-0.88]) decreased the odds of being exposed. The Hosmer-Lemeshow test revealed good calibration $(p=0.455)$ and the predictive power was good (AUC $=0.765)$.

When analyzed by gender, the effect of current asthma was maintained only for female; being a current smoker presented the highest adjusted OR for both genders (Table 4).

\section{Current smoking}

Nineteen percent of the Portuguese population was CS and $17.2 \%$ were ex-smokers (Table 3 ). Regarding individuals with $\geq 18$ years, $19.8 \%$ were CS. The highest proportion of CS was seen in the $35-44$ age group (30.2\%) with a progressive drop thereafter. In the age groups older than 44 years, the prevalence of ex-smokers exceeded the CS. Overall, there was a higher prevalence of CS in males compared to females $(26.5 \%$ vs. $12.2 \%$, respectively; $p<0.001)$; this relation was consistent in all the age groups. In men, the 
Table 3 Weighted average rate (\%) of current smokers, non-smokers, ex-smokers and exposure to environmental tobacco smoke (ETS) at home according to demographic characteristics and disease status.

\begin{tabular}{|c|c|c|c|c|}
\hline & $\begin{array}{l}\text { Non-smokers } \\
\%[95 \% \mathrm{CI}]\end{array}$ & $\begin{array}{l}\text { Current smokers } \\
\%[95 \% \mathrm{Cl}]\end{array}$ & $\begin{array}{l}\text { Ex-smokers } \\
\%[95 \% \mathrm{CI}]\end{array}$ & $\begin{array}{l}\text { Exposed to ETS } \\
\text { at home } \\
\%[95 \% \mathrm{Cl}]\end{array}$ \\
\hline TOTAL & $63.8[62.6-65.0]$ & $19.0[18.0-20.0]$ & $17.2[16.2-18.2]$ & $26.6[25.5-27.7]$ \\
\hline \multicolumn{5}{|l|}{ Gender } \\
\hline Male & $48.4[46.3-50.5]$ & 26.5 [24.7-28.3] & $25.1[23.3-26.9]$ & $24.8[23.1-26.5]$ \\
\hline Female & $77.7[76.3-79.1]$ & $12.2[11.1-13.3]$ & $10.1[9.1-11.1]$ & $28.3[26.8-29.8]$ \\
\hline \multicolumn{5}{|l|}{ Age groups } \\
\hline$<18$ years old ${ }^{\mathrm{a}}$ & - & - & - & $36.7[33.2-40.2]$ \\
\hline 18-65 years old & $59.3[57.6-61.0]$ & $23.7[22.2-25.2]$ & $17.0[15.7-18.3]$ & $27.9[26.3-29.5]$ \\
\hline$\geq 65$ years old & $73.7[71.9-75.5]$ & $4.4[3.5-5.3]$ & $21.8[20.1-23.5]$ & $9.1[7.9-10.3]$ \\
\hline \multicolumn{5}{|l|}{ Region } \\
\hline North & $66.9[64.7-69.1]$ & $16.4[14.7-18.1]$ & $16.8[15.1-18.5]$ & $23.4[21.5-25.3]$ \\
\hline Center & $63.4[60.8-66.0]$ & $17.9[15.8-20.0]$ & $18.7[16.6-20.8]$ & $26.0[23.7-28-3]$ \\
\hline Lisbon & $58.8[56.3-61.3]$ & $22.8[20.7-24.9]$ & $18.4[16.5-20.3]$ & $29.2[27.0-31.4]$ \\
\hline Alentejo/Algarve & $64.8[61.2-68.4]$ & $21.0[17.9-24.1]$ & $14.2[11.6-16.8]$ & $28.7[25.4-32.0]$ \\
\hline Madeira and Azores islands & $68.3[61.9-74.7]$ & $18.2[12.9-23.5]$ & $13.5[8.8-18.2]$ & $36.6[30.5-42.7]$ \\
\hline \multicolumn{5}{|l|}{ Socioeconomic status } \\
\hline Low & $79.1[76.8-81.4]$ & $10.7[9.0-12.4]$ & $10.2[8.5-11.9]$ & $16.2[14.2-18.2]$ \\
\hline Medium & $61.3[59.7-62.9]$ & $20.4[19.1-21.7]$ & $18.3[17.1-19.5]$ & $28.0[26.6-29.4]$ \\
\hline High & $58.2[53.0-63.4]$ & $22.9[18.5-27.3]$ & $18.9[14.8-23.0]$ & $29.2[24.8-33.6]$ \\
\hline \multicolumn{5}{|l|}{ School education ( $\geq 18$ years old) } \\
\hline$<9$ years & $66.8[65.2-68.4]$ & $16.0[14.8-17.2]$ & $17.2[15.9-18.5]$ & $19.2[17.9-20.5]$ \\
\hline $9-12$ years & $55.8[52.8-58.8]$ & $25.6[23.0-28.2]$ & $18.5[16.2-20.8]$ & $31.8[29.0-34.6]$ \\
\hline$>12$ years & $58.6[55.0-62.2]$ & $22.1[19.1-25.1]$ & $19.3[16.4-22.2]$ & $25.8[22.6-29.0]$ \\
\hline \multicolumn{5}{|l|}{ BMI groups ( $\geq 18$ years old $)$} \\
\hline$<25 \mathrm{~kg} / \mathrm{m}^{2}$ & $60.4[58.2-62.6]$ & $22.5[20.7-24.3]$ & $17.1[15.4-18.8]$ & $29.0[27.0-31.0]$ \\
\hline $25-29.99 \mathrm{~kg} / \mathrm{m}^{2}$ & $57.4[55.1-60.0]$ & $21.8[20.0-23.7]$ & $20.7[18.8-22.6]$ & $20.7[18.8-22.6]$ \\
\hline$\geq 30 \mathrm{~kg} / \mathrm{m}^{2}$ & $60.9[57.3-64.5]$ & $14.9[12.3-17.5]$ & $24.2[21.0-27.4]$ & $21.2[18.2-24.2]$ \\
\hline \multicolumn{5}{|l|}{ Persons in the household } \\
\hline$\leq 2$ persons & $64.9[63.3-66.5]$ & $15.9[14.7-17.1]$ & $19.2[17.9-20.5]$ & $14.4[13.2-15.6]$ \\
\hline 3 persons & $60.4[57.4-63.4]$ & $24.5[21.9-27.1]$ & $15.1[12.9-17.3]$ & $28.1[25.5-30.7]$ \\
\hline$\geq 4$ persons & $65.0[62.2-67.8]$ & $18.0[15.8-20.2]$ & $17.0[14.8-19.2]$ & $32.9[30.5-35.3]$ \\
\hline \multicolumn{5}{|l|}{ Current asthma } \\
\hline Yes & $65.9[61.3-70.5]$ & $17.8[14.1-21.5]$ & $16.3[12.7-20.0]$ & $33.8[29.4-38.2]$ \\
\hline No & $63.6[62.3-65.0]$ & $19.1[18.0-20.1]$ & $17.3[16.3-18.3]$ & $26.1[24.9-27.3]$ \\
\hline \multicolumn{5}{|l|}{ Self-reported heart disease } \\
\hline Yes & $66.6[63.4-69.8]$ & 7.8 [6.0-9.6] & 25.5 [22.5-28.5] & $16.0[13.5-18.5]$ \\
\hline No & $63.5[62.1-64.9]$ & $20.1[18.9-21.3]$ & $16.4[15.3-17.5]$ & $27.5[26.3-28.7]$ \\
\hline
\end{tabular}

95\% Cl: 95\% confidence interval; ETS: Environmental tobacco smoke; BMI: body mass index.

a For non-smoking, smoking and ex-smoking this category would only include participants aged between15 and 17 years old (not presented).

35-44 years age group was the only one with a higher proportion of CS than never-smokers (39.6\% vs. $38.9 \%)$; in women, the prevalence of CS was always lower than the never-smokers.

We found a higher prevalence of CS in those with higher SES; when analyzed by gender this association was present only in females.

The mean (SD) starting age of smoking was 17.2 (4.2) years (17.2 (3.5) in men vs. $17.6(4.8)$ in women, $p<0.001)$.
One in five $(21.6 \%)$ started smoking before the age of 15 years.

Current smoking men, on average, smoked more cigarettes per day than women $(14.9$ (13.2) vs. 10.6 (7.4), $p<0.001)$. Almost $10 \%(7.9 \%)$ of the CS smoked $>20$ cigarettes per day $(10.7 \%$ of CS men, $2.5 \%$ of CS women, $p<0.001$ ).

No differences were found in CS prevalence when comparing individuals with asthma with the general population 
Table 4 Odds ratio (OR) of being exposed to ETS at home (for adults with at least one other person in the household), stratified by gender.

\begin{tabular}{|c|c|c|c|c|}
\hline \multirow[t]{2}{*}{ Factors } & \multicolumn{2}{|c|}{ Female $(n=1561)$} & \multicolumn{2}{|c|}{ Male $(n=1140)$} \\
\hline & $\begin{array}{l}\text { Unadjusted OR } \\
{[95 \% \mathrm{CI}]}\end{array}$ & $\begin{array}{l}\text { Adjusted OR } \\
{[95 \% \mathrm{CI}]}\end{array}$ & $\begin{array}{l}\text { Unadjusted OR } \\
{[95 \% \mathrm{CI}]}\end{array}$ & $\begin{array}{l}\text { Adjusted OR } \\
{[95 \% \mathrm{CI}]}\end{array}$ \\
\hline \multicolumn{5}{|l|}{ Age groups } \\
\hline$\geq 65$ years old ${ }^{a}$ & $0.45[0.36-0.58]$ & $0.74[0.52-1.05]$ & $0.18[0.12-0.26]$ & $0.45[0.26-0.78]$ \\
\hline Region & $0.046^{b}$ & $\mathrm{NI}$ & $0.047^{b}$ & $\mathrm{NI}$ \\
\hline North & 1 & & 1 & \\
\hline Center & $0.92[0.70-1.21]$ & & $1.14[0.81-1.58]$ & \\
\hline Lisbon & $1.16[0.89-1.51]$ & & $1.06[0.77-1.47]$ & \\
\hline Alentejo/Algarve & $1.21[0.89-1.66]$ & & $1.74[1.18-2.55]$ & \\
\hline Madeira and Azores islands & $1.77[1.12-2.77]$ & & $1.66[0.84-3.25]$ & \\
\hline Socioeconomic status & $0.030^{\mathrm{b}}$ & $0.409^{b}$ & $<0.001^{\mathrm{b}}$ & $0.104^{b}$ \\
\hline Lower & 1 & 1 & 1 & 1 \\
\hline Medium & $1.26[0.97-1.64]$ & $0.79[0.54-1.14]$ & $2.77[1.66-4.62]$ & $1.89[0.97-3.68]$ \\
\hline Upper & $1.78[1.15-2.75]$ & $0.88[0.47-1.68]$ & $3.62[1.94-6.78]$ & $2.52[1.03-6.16]$ \\
\hline School education & $<0.001^{b}$ & $0.670^{\mathrm{b}}$ & $<0.001^{b}$ & $0.037^{b}$ \\
\hline$<9$ years & 1 & 1 & 1 & 1 \\
\hline $9-12$ years & $1.58[1.23-2.00]$ & $0.91[0.65-1.26]$ & $2.42[1.84-3.18]$ & $1.62[1.12-2.34]$ \\
\hline$>12$ years & $1.47[1.12-1.92]$ & $0.84[0.56-1.26]$ & $1.88[1.32-2.68]$ & $1.22[0.70-2.11]$ \\
\hline$B M I$ groups & $0.065^{b}$ & $0.744^{\mathrm{b}}$ & $<0.001^{b}$ & $<0.001^{b}$ \\
\hline$<25 \mathrm{~kg} / \mathrm{m}^{2}$ & 1 & 1 & 1 & 1 \\
\hline $25-29.99 \mathrm{~kg} / \mathrm{m}^{2}$ & $0.75[0.59-0.96]$ & $0.90[0.67-1.19]$ & $0.50[0.38-0.65]$ & $0.52[0.37-0.74]$ \\
\hline$\geq 30 \mathrm{~kg} / \mathrm{m}^{2}$ & $0.92[0.68-1.24]$ & $0.97[0.68-1.40]$ & $0.29[0.18-0.48]$ & $0.52[0.28-0.98]$ \\
\hline Persons in the household & $<0.001^{b}$ & $<0.001^{\mathrm{b}}$ & $<0.001^{\mathrm{b}}$ & $0.002^{b}$ \\
\hline$\leq 2$ persons & 1 & 1 & 1 & 1 \\
\hline 3 persons & $2.17[1.70-2.79]$ & $2.07[1.50-2.87]$ & $2.40[1.75-3.29]$ & $1.00[0.65-1.54]$ \\
\hline$\geq 4$ persons & $2.72[2.15-3.45]$ & $2.57[1.88-3.51]$ & $3.51[2.60-4.73]$ & $1.87[1.23-2.84]$ \\
\hline \multicolumn{5}{|l|}{ Current asthma } \\
\hline Yes & $1.84[1.33-2.56]$ & $2.90[1.90-4.41]$ & $0.79[0.45-1.39]$ & $0.90[0.44-1.84]$ \\
\hline \multicolumn{5}{|l|}{ Self-reported heart disease } \\
\hline Yes & $0.57[0.41-0.79]$ & $0.75[0.48-1.17]$ & $0.50[0.31-0.78]$ & $1.21[0.60-2.44]$ \\
\hline \multicolumn{5}{|l|}{ Smoking status } \\
\hline Current smoker (vs. never smoker) & $7.75[5.69-10.56]$ & $7.82[5.49-11.12]$ & $6.81[5.06-9.16]$ & $7.09[5.08-9.88]$ \\
\hline
\end{tabular}

Statistically significant results are presented in bold.

ETS: environmental tobacco smoke; $95 \% \mathrm{Cl}$ : $95 \%$ confidence interval; BMI: body mass index; NI: not included

a Reference: $18-64$ years old.

b $p$-Value for trend.

(17.8\% vs. $19.0 \%$, respectively). Those with heart disease had the lowest CS prevalence (7.8\%) and the highest prevalence of ex-smokers $(25.5 \%$ vs. $16.3 \%$ in those with asthma vs. 17.2 in the general population) (Table 3).

In the adjusted multiple logistic regression model for CS in adults (Table S4), the odds of being a CS was higher for the male gender, the more educated and those exposed to ETS at home $(\mathrm{OR}=7.32$ [5.93-9.17]). Being $\geq 65$ years $(O R=0.41[0.31-0.54])$ decreased the odds of being CS. The Hosmer-Lemeshow test revealed good calibration $(p=0.760)$ and the predictive power was high (AUC = 0.839).

When analyzed by gender, the effect of school education was maintained only for female (Table 5).

\section{Discussion}

Our study showed that the prevalence of exposure to ETS at home in the general Portuguese population was $26.6 \%$; children and young adults were the most exposed (39.0\%). The prevalence of tobacco smoking in the general population was $19.0 \%$. Having current asthma was positively associated with exposure to ETS.

\section{Prevalence of exposure to ETS at home}

The effect of the new tobacco control policies in the prevalence of ETS exposure at home cannot be accurately assessed as results of the available studies are difficult to 
Table 5 Odds ratio (OR) of being a current smoker (vs. never smoker) in adults, stratified by gender.

\begin{tabular}{|c|c|c|c|c|}
\hline \multicolumn{5}{|l|}{ Age groups } \\
\hline$\geq 65$ years old ${ }^{a}$ & $0.10[0.07-0.15]$ & $0.33[0.20-0.54]$ & $0.34[0.25-0.44]$ & $0.45[0.32-0.63]$ \\
\hline Region & $<0.001^{b}$ & $\mathrm{NI}$ & $0.129^{b}$ & $\mathrm{NI}$ \\
\hline North & 1 & & 1 & \\
\hline Center & $1.02[0.68-1.50]$ & & $0.86[0.63-1.16]$ & \\
\hline Lisbon & $2.13[1.52-2.98]$ & & $1.26[0.95-1.66]$ & \\
\hline Alentejo/Algarve & $1.58[1.04-2.40]$ & & $1.27[0.87-1.84]$ & \\
\hline Madeira and Azores islands & $2.29[1.31-4.03]$ & & $1.07[0.54-2.14]$ & \\
\hline Socioeconomic status & $<0.001^{\mathrm{b}}$ & $0.021^{b}$ & $0.002^{\mathrm{b}}$ & $0.207^{b}$ \\
\hline Lower & 1 & 1 & 1 & 1 \\
\hline Medium & $10.84[6.03-19.50]$ & $2.52[1.29-4.93]$ & $1.90[1.32-2.72]$ & 1.39 [0.89-2.17] \\
\hline Upper & $28.55[14.24-57.24]$ & $2.94[1.25-6.88]$ & $1.86[1.12-3.09]$ & $1.03[0.51-2.08]$ \\
\hline School education & $<0.001^{b}$ & $<0.001^{b}$ & $0.011^{b}$ & $0.885^{b}$ \\
\hline$<9$ years & 1 & 1 & 1 & 1 \\
\hline $9-12$ years & $7.24[5.28-9.93]$ & $3.22[2.21-4.70]$ & $1.42[1.10-1.83]$ & $0.96[0.70-1.30]$ \\
\hline$>12$ years & $8.70[6.25-12.10]$ & $3.64[2.37-5.59]$ & $1.39[1.01-1.90]$ & $1.07[0.67-1.70]$ \\
\hline BMI groups & $<0.001^{\mathrm{b}}$ & $0.138^{\mathrm{b}}$ & $0.009^{b}$ & $0.048^{b}$ \\
\hline$<25 \mathrm{~kg} / \mathrm{m}^{2}$ & 1 & 1 & 1 & 1 \\
\hline 25 to $29.99 \mathrm{~kg} / \mathrm{m}^{2}$ & $0.41[0.30-0.56]$ & $0.70[0.49-0.99]$ & $0.91[0.71-1.15]$ & $1.25[0.95-1.66]$ \\
\hline$\geq 30 \mathrm{~kg} / \mathrm{m}^{2}$ & $0.44[0.29-0.66]$ & $0.84[0.53-1.34]$ & $0.51[0.33-0.79]$ & $0.73[0.45-1.18]$ \\
\hline Persons in the household & $<0.001^{b}$ & $\mathrm{NI}$ & $0.017^{b}$ & $\mathrm{NI}$ \\
\hline$\leq 2$ persons & 1 & & 1 & \\
\hline 3 persons & $2.03[1.47-2.79]$ & & $1.47[1.12-1.93]$ & \\
\hline$\geq 4$ persons & $1.97[1.44-2.68]$ & & $1.23[0.93-1.62]$ & \\
\hline \multicolumn{5}{|l|}{ Current asthma } \\
\hline Yes & $0.88[0.54-1.41]$ & $0.67[0.37-1.22]$ & $0.86[0.53-1.40]$ & $0.89[0.50-1.58]$ \\
\hline \multicolumn{5}{|l|}{ Self-reported heart disease } \\
\hline Yes & $0.27[0.16-0.45]$ & $1.00[0.54-1.83]$ & $0.75[0.50-1.11]$ & $1.26[0.78-2.04]$ \\
\hline \multicolumn{5}{|l|}{ Exposure to ETS at home } \\
\hline Exposed & $10.14[7.74-13.28]$ & $7.30[5.36-9.92]$ & $7.91[5.93-10.55]$ & $7.47[5.46-10.21]$ \\
\hline
\end{tabular}

Statistically significant results are presented in bold.

95\% CI: 95\% confidence interval; BMI: body mass index; ETS: environmental tobacco smoke; NI: not included.

a Reference: 18-64 years old.

b $p$-Value for trend.

compare: study questions and definitions of exposure are widely variable and most reports don't present explicit data on home exposure. ${ }^{12,14,18,24}$ The National Health Survey $2005-2006,{ }^{14}$ for example, refers to the exposure to ETS in closed spaces but not specifically at home. The Eurobarometer study held in $2006^{18}$ reported that the prevalence of participants in whose homes smoking was not allowed was $29 \%$, suggesting that about $71 \%$ of the population was potentially exposed to ETS at home; in the Eurobarometer 332 (from 2009), ${ }^{12}$ potential exposure was reduced to $34 \%$ of the population. To the best of our knowledge, the definition used in our study is similar to only one recent Portuguese report, ECOS2010 15 ; that study, carried out in 2010 , estimated that $15.7 \%$ of the Portuguese population was exposed inside their homes, which is much lower than the prevalence we report. There are some methodological differences that might explain this discrepancy: the ECOS2010 study collected data from a sample of Portuguese families willing to be periodically contacted to answer health surveys (ECOS panel); only individuals with $\geq 18$ years were asked to participate and there was no random selection inside each household.

Our results are in agreement with other studies ${ }^{25-28}$ in relation to a high prevalence of exposure among children and adolescents.

\section{Prevalence of current tobacco smoking}

The prevalence of tobacco smoking in Portugal, in this study, was lower than in reports prior to the 2008 tobacco law (Fig. 1).

Recent studies, ${ }^{12,14,15}$ conducted after the 2008 smoking bans, presented prevalence estimates of CS in Portugal that ranged between $16.4 \%$ and $25.5 \%$; our estimate is in the same range. This wide range probably reflects different survey methods, different definitions and different samples 

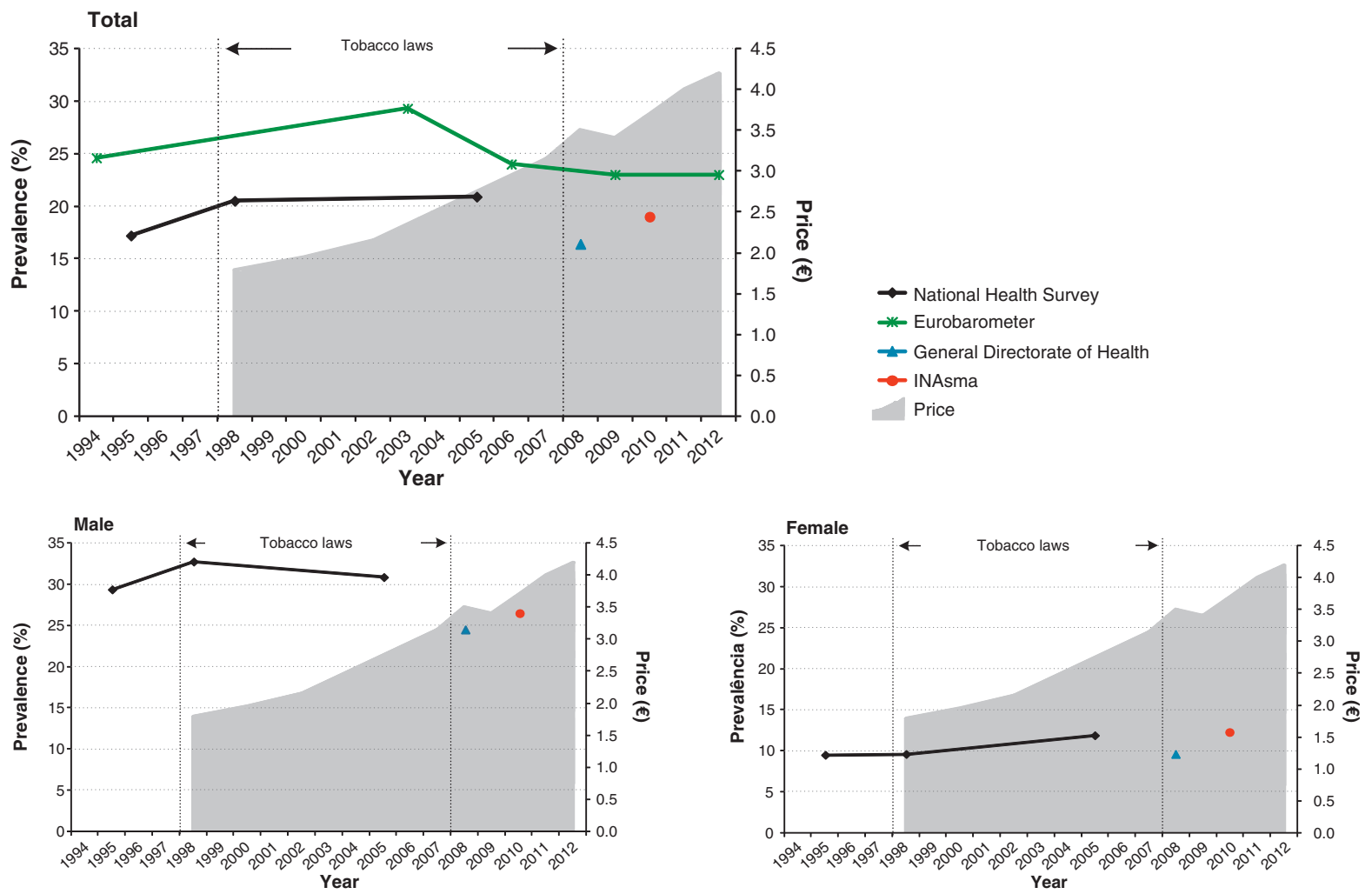

Figure 1 Prevalence of tobacco smoking in the population aged 15 years or more in Portugal (data since 1994) and evolution of tobacco price (pack of premium brand); stratification by gender is also presented. ${ }^{12,15,18,24}$

sizes. ${ }^{12,14,24}$ The slight decreasing tendency of the prevalence of smoking, shown in Fig. 1, does not seem to be directly related with the increase in tobacco price or more restrictive smoking bans. The previously reported genderspecific trends ${ }^{13}$ are also supported by the data of this study: CS prevalence in females has been rising in the last 15 years while, in males, there was a gradual decrease (Fig. 1).

The higher CS prevalence in women with higher SES is in agreement with other data for Portugal29-31 but differs from other countries'. ${ }^{30-32}$ This discrepancy may be related to differences in the stage of the smoking epidemic, ${ }^{30,31}$ but the economic capacity to pay for cigarettes may also have a strong impact. ${ }^{29}$

Those exposed to home ETS presented the highest adjusted OR for smoking. This may suggest that ETS exposure is a risk factor for smoking initiation. ${ }^{25,33,34}$

\section{Prevalence of smoking and ETS exposure in individuals with asthma or self-reported heart disease}

As far as we know, in Portugal, no other populationbased study has estimated the prevalence of smoking and home exposure to ETS in individuals with asthma or heart disease.

The low smoking prevalence in subjects with heart disease suggests that these individuals have some awareness of the harmful influence of tobacco use in heart pathologies. ${ }^{35}$

The consequences of smoking and ETS exposure on asthmatics ${ }^{36-39}$ and the beneficial effects of a smoke-free legislation (e.g. associated with a lower rate of hospitalizations for childhood asthma ${ }^{17}$ ) are increasingly recognized. In spite of this knowledge, we found a smoking prevalence in asthmatics that is similar to the general population; other population-based studies reported similar findings. ${ }^{39-45}$ To the best of our knowledge, the only Portuguese study ${ }^{46}$ reporting a CS prevalence in asthmatics was held in an asthma clinic; the prevalence was $8 \%$. This low prevalence was explained by a possible selection bias in relation with regular follow-up by lung physicians. ${ }^{46}$

Several reports found a prevalence of ETS exposure at home in asthmatics similar to the general population. ${ }^{41,47,48}$ In our study, on the contrary, ETS exposure was higher in asthmatics; this is in agreement with the findings of Leech et al. ${ }^{49}$ in Canada. In that study, it was suggested that this higher prevalence could be explained by an increased reporting related to greater awareness of smoke exposure in asthmatics. ${ }^{49}$ However, when interpreting these findings and considering the cross-sectional nature of our study, we cannot exclude the possibility of reverse causality (exposure to ETS at home may be a cause of asthma)

\section{Limitations}

The sampling process, using landline telephone numbers, may be a limitation because of the increasing number of mobile-only households and resistance to telephone surveying ${ }^{50}$; it may also introduce a selection bias, with under-representation of some groups', including CS. ${ }^{51}$ 
However, the use of the mobile telephone network as an alternative would not give a geographical stratification, would reduce the control of the sampling process and has lower response rates. ${ }^{51}$ The fact that the only available data at the time of the data collection were from the 2001 National Census may be another limitation because demographic changes in recent years could have influenced the sampling methods; however the data from the 2011 Census necessary for the weighting procedures had not yet been published.

Smoking/exposure status was self-reported which can lead to underreporting of smoking habits. ${ }^{52,53}$ The definition of current smoking used in this study did not include occasional smokers in CS or as an independent group; the inclusion of occasional smokers would be an added value for the study and its absence might lead to an under-estimation of the total current smoking prevalence. Moreover, only home exposure to ETS was questioned limiting the comparability with other reports.

The definition of diseases using questionnaires has been widely used; however, several combinations are accepted. The one we chose was associated with a higher specificity and lower asthma prevalence. ${ }^{20}$

Repeated population surveys using representative, randomly selected samples of sufficiently large size, with similar questionnaires and definitions is the only way to provide comparable estimates of smoking and ETS exposure prevalence. ${ }^{2}$ Methods to improve reporting accuracy (e.g. cotinine saliva) are reserved for smaller samples and may be part of a future study.

In conclusion, exposure to environmental tobacco smoke at home in Portugal is higher than in a previous report using the same definition. Our results suggest that children/adolescents and asthmatics, but not individuals with heart disease, may be at higher risk for home exposure to environmental tobacco smoke. This study supports a decreasing trend of the prevalence of tobacco smoking in Portuguese male, but a tendency to increase in female.

\section{Ethical disclosures}

Protection of human and animal subjects. The authors declare that no experiments were performed on humans or animals for this study.

Confidentiality of data. The authors declare that they have followed the protocols of their work center on the publication of patient data and that all the patients included in the study received sufficient information and gave their written informed consent to participate in the study.

Right to privacy and informed consent. The authors declare that no patient data appear in this article.

\section{Funding}

The underlying research was funded by Sociedade Portuguesa de Alergologia e Imunologia Clínica and Sociedade Portuguesa de Pneumologia.

\section{Conflicts of interest}

The underlying research was funded by Sociedade Portuguesa de Alergologia e Imunologia Clínica and Sociedade Portuguesa de Pneumologia.

\section{Acknowledgement}

We thank Professor Luís Delgado for his input and cooperation with this work.

\section{Appendix A. Supplementary data}

Supplementary material related to this article found, in the online version, at doi:10.1016/j.rppnen.2013.01.006.

\section{References}

1. European Commission ASPECT Consortium. Tobacco or health in the European Union: past, present and future. Luxembourg: European Commission. Available at: http://ec.europa.eu/ health/ph_determinants/life_style/Tobacco/Documents/ tobacco_fr_en.pdf

2. World Health Organization. WHO Report on the Global Tobacco Epidemic, 2009: implementing smoke-free environments. Geneva: WHO; 2009.

3. US Department of Health and Human Services. The health consequences of smoking: a report of the surgeon general. Atlanta: Centers for Disease Control and Prevention, National Center for Chronic Disease Prevention and Health Promotion, Office on Smoking and Health; 2004.

4. US Department of Health and Human Services. The health consequences of involuntary exposure to tobacco smoke: a report of the surgeon general. Atlanta: Centers for Disease Control and Prevention, Coordinating Center for Health Promotion, National Center for Chronic Disease Prevention and Health Promotion, Office on Smoking and Health; 2006.

5. Action on smoking and health (ASH-UK). Tobacco: global trends; 2007 [updated August 2007; cited September 2011]. Available ate: http://www.ash.org.uk/files/documents/ASH_562.pdf

6. Oberg M, Jaakkola MS, Woodward A, Peruga A, Prüss-Ustün A. Worldwide burden of disease from exposure to second-hand smoke: a retrospective analysis of data from 192 countries. Lancet. 2011;377:139-46.

7. McClave AK, Whitney N, Thorne SL, Mariolis P, Dube SR, Engstrom M. Adult tobacco survey - 19 states, 2003-2007. MMWR Surveill Summ. 2010;59:1-75.

8. Levy DT, Chaloupka F, Gitchell J. The effects of tobacco control policies on smoking rates: a tobacco control scorecard. J Public Health Manage Pract. 2004;10:338-53.

9. World Health Organization. WHO framework convention on tobacco control. Geneva: WHO; 2003.

10. Assembleia da República. Lei n. ${ }^{\circ} 37 / 2007$ de 14 de agosto. Diário da República. 2007; $1 .^{\mathrm{a}}$ série (156): 5277-85.

11. Instituto Nacional de Estatística, Instituto Nacional Doutor Ricardo Jorge. 4. Inquérito Nacional de Saúde 2005/2006: Destaque. Lisboa; 2009.

12. TNS Opinion \& Social. Special Eurobarometer 332: tobacco. Brussels: European Commission [cited April 2011]. Available at: http://ec.europa.eu/public_opinion/archives/ebs/ebs_332_en. pdf 
13. Precioso J, Calheiros J, Pereira D, Campos H, Antunes H, Rebelo $\mathrm{L}$, et al. Prevalence and smoking trends in Portugal and Europe. Acta Med Port. 2009;22:335-48.

14. INFOTABAC, Direção-Geral de Saúde. Avaliação Intercalar do Impacte da Nova Legislação de Prevenção do Tabagismo (Lei 37/2007, de 14 de agosto) [updated April 2010; cited February 2011]. Available at: http: //www.dgs.pt/upload/ membro.id/ficheiros/i012662.pdf

15. Direção-Geral da Saúde. Avaliação da lei do tabaco em Portugal 2008-2010. Infotabac relatório: Primeira avaliação do impacto da aplicação da Lei do Tabaco. Direção-Geral de Saúde, Instituto Nacional de Saúde Doutor Ricardo Jorge [updated April 2011; cited September 2011]. Available at: http://www.coppt.pt/ attachments/186_201103-i014123.pdf

16. Akhtar PC, Haw SJ, Currie DB, Zachary R, Currie CE. Smoking restrictions in the home and secondhand smoke exposure among primary schoolchildren before and after introduction of the Scottish smoke-free legislation. Tob Control. 2009;18: 409-15.

17. Mackay D, Haw S, Ayres JG, Fischbacher C, Pell JP. Smoke-free legislation and hospitalizations for childhood asthma. N Engl J Med. 2010;363:1139-45.

18. TNS Opinion \& Social. Special Eurobarometer 272c/Wave 66.2: attitudes of Europeans towards tobacco. Brussels: European Commission [cited May 2011]. Available at: http://ec. europa.eu/health/ph_determinants/life_style/Tobacco/ Documents/ebs272c_en.pdf

19. Contreiras T, Nunes B, Branco MJ. Em Casa, pelo telefone, Observamos Saúde: Descrição e avaliação de uma metodologia. Instituto Nacional de Súde Ricardo Jorge [updated 2003; cited September 2011]. Available at: http://www.insa.pt/sites/ INSA/Portugues/Publicacoes/Outros/Documents/Epidemiologia/ proj_ecos_ecptos_onsa.pdf

20. Sa-Sousa A, Morais-Almeida M, Azevedo LF, Carvalho R, Jacinto T, Todo-Bom A, et al. Prevalence of asthma in Portugal - the Portuguese National Asthma Survey. Clin Transl Allergy. 2012;2:15.

21. Burney P, Jarvis D. Protocol for the European Community Respiratory Health Survey II. London; 2002.

22. Burney PG, Luczynska C, Chinn S, Jarvis D. The European Community Respiratory Health Survey. Eur Respir J. 1994;7: 954-60.

23. World Health Organization. Obesity: preventing and managing the global epidemic. Geneva: WHO; 2000.

24. Machado A, Nicolau R, Matias Dias C. Tobacco consumption by the portuguese population. Data from the 2005-2006 National Health Survey. Rev Port Pneumol. 2009;15: 1005-27.

25. Lacerda AC, Cardoso MF. Smoking among Portuguese teenagers: assessing school, peer and family factors of vulnerability and protection. Rev Port Saúde Pública. 2009;27:17-25.

26. Constant C, Sampaio I, Negreiro F, Aguiar P, Silva AM, Salgueiro $M$, et al. Environmental tobacco smoke (ETS) exposure and respiratory morbidity in school age children. Rev Port Pneumol. 2011;17:20-6.

27. Precioso J, Samorinha C, Calheiros JM, Macedo M, Antunes $\mathrm{H}$, Campos $\mathrm{H}$. Second hand smoke (SHS) exposure in children. An evaluation of a preventative measure. Rev Port Pneumol. 2010;16:57-72.

28. Kum-Nji P, Meloy L, Herrod HG. Environmental tobacco smoke exposure: prevalence and mechanisms of causation of infections in children. Pediatrics. 2006;117:1745-54.

29. Santos AC, Barros H. Smoking patterns in a community sample of Portuguese adults, 1999-2000. Prev Med. 2004;38: 114-9.

30. Cavelaars AE, Kunst AE, Geurts JJ, Crialesi R, Grötvedt L, Helmert $U$, et al. Educational differences in smoking: international comparison. Br Med J. 2000;320:1102-7.
31. Huisman M, Kunst A, Mackenbach J. Educational inequalities in smoking among men and women aged 16 years and older in 11 European countries. Tob Control. 2005;14: 106-13.

32. Schaap MM, Kunst AE, Leinsalu M, Regidor E, Espelt A, Ekholm $O$, et al. Female ever-smoking, education, emancipation and economic development in 19 European countries. Soc Sci Med. 2009;68:1271-8.

33. Voorhees CC, Ye C, Carter-Pokras O, MacPherson L, Kanamori $M$, Zhang $G$, et al. Peers, tobacco advertising, and secondhand smoke exposure influences smoking initiation in diverse adolescents. Am J Health Promot. 2011;25: e1-11.

34. Wang MP, Ho SY, Lam TH. Parental smoking, exposure to secondhand smoke at home, and smoking initiation among young children. Nicotine Tob Res. 2011;13:827-32.

35. Barnoya J, Glantz SA. Cardiovascular effects of secondhand smoke: nearly as large as smoking. Circulation. 2005;111:2684-98

36. Vignoud L, Pin I, Boudier A, Pison C, Nadif R, Le Moual N, et al. Smoking and asthma: disentangling their mutual influences using a longitudinal approach. Respir Med. 2011;105: 1805-14.

37. Thomson NC, Chaudhuri R, Livingston E. Active cigarette smoking and asthma. Clin Exp Allergy. 2003;33:1471-5.

38. Pietinalho A, Pelkonen A, Rytilä P. Linkage between smoking and asthma. Allergy. 2009;64:1722-7.

39. Siroux V, Pin I, Oryszcyn MP, Le Moual N, Kauffmann F. Relationships of active smoking to asthma and asthma severity in the EGEA study. Epidemiological study on the Genetics and Environment of Asthma. Eur Respir J. 2000;15: 470-7.

40. Thomson NC, Chaudhuri R, Livingston E. Asthma and cigarette smoking. Eur Respir J. 2004;24:822-33.

41. Silverman RA, Boudreaux ED, Woodruff PG, Clark S, Camargo CA. Cigarette smoking among asthmatic adults presenting to 64 emergency departments. Chest. 2003;123: 1472-9.

42. Turner MO, Noertjojo K, Vedal S, Bai T, Crump S, Fitzgerald JM. Risk factors for near fatal asthma. A case-control study in hospitalized patients with asthma. Am J Respir Crit Care Med. 1998;157:1804-9.

43. Patel SN, Tsai CL, Boudreaux ED, Kilgannon JH, Sullivan AF, Blumenthal D, et al. Multicenter study of cigarette smoking among patients presenting to the emergency department with acute asthma. Ann Allergy Asthma Immunol. 2009;103: 121-7.

44. Eisner MD, Yelin EH, Trupin L, Blanc PD. Asthma and smoking status in a population-based study of California adults. Public Health Rep. 2001;116:148-57.

45. Vozoris NT, Stanbrook MB. Smoking prevalence, behaviours, and cessation among individuals with COPD or asthma. Respir Med. 2011;105:477-84.

46. Seabra B, Guimarães $M$, Carvalho A, Duarte R. The smoking rate and its repercussions on an asthmatic population sample. Rev Port Pneumol. 2008;14:617-24.

47. Yun S, Chanetsa F, Kelsey A, Zhu B-P. Active and passive smoking among asthmatic Missourians: implications for health education. Prev Med. 2006;42:286-90.

48. Gupta D, Aggarwal AN, Chaudhry K, Chhabra SK, D'Souza GA, Jindal SK, et al. Household environmental tobacco smoke exposure, respiratory symptoms and asthma in non-smoker adults: a multicentric population study from India. Indian J Chest Dis Allied Sci. 2006;48:31-6.

49. Leech JA, Wilby K, McMullen E. Environmental tobacco smoke exposure patterns: a subanalysis of the Canadian Human Time-Activity Pattern Survey. Can J Public Health. 1999;90: 244-9. 
50. Boland M, Sweeney MR, Scallan E, Harrington M, Staines A. Emerging advantages and drawbacks of telephone surveying in public health research in Ireland and the UK. BMC Public Health. 2006;6:208.

51. Grande D, Taylor AW. Sampling and coverage issues of telephone surveys used for collecting health information in Australia: results from a face-to-face survey from 1999 to 2008. BMC Med Res Methodol. 2010;10:77.
52. Wells AJ, English PB, Posner SF, Wagenknecht LE, PerezStable EJ. Misclassification rates for current smokers misclassified as nonsmokers. Am J Public Health. 1998;88: 1503-9.

53. Wagenknecth LE, Burke GL, Perkins LL, Haley NJ, Friedman GD. Misclassification of smoking status in the CARDIA study: a comparison of self-report with serum continine levels. Am J Public Health. 1992;82:33-6. 